\title{
« Plural-entrepreneurial activity for a single start-up: a case of study »
}

\section{$\underline{\text { Auteur }}$}

\author{
Thierry BURGER-HELMCHEN
}

Document de Travail $n^{\circ} 2008$ - 1

Janvier 2008

Faculté des sciences économiques et de gestion

Pôle européen de gestion et d'économie (PEGE) 61 avenue de la Forêt Noire F-67085 Strasbourg Cedex

Secrétariat du BETA Géraldine Manderscheidt Tél. : (33) 0390242069 Fax : (33) 0390242070 manderscheidt@cournot.ustrasbg.fr 


\title{
Plural-entrepreneurial activity for a single start-up: a case study ${ }^{*}$
}

\author{
Thierry BURGER-HELMCHEN
}

BETA - Bureau d'Économie Théorique et Appliquée

Research Unit $n^{\circ} 7522$ of the CNRS

61, avenue de la Forêt Noire

67085 Strasbourg Cedex

FRANCE

Email : burger@cournot.u-strasbg.fr

Phone : (0033) 390242089

Fax : (0033) 390242071

\begin{abstract}
:
Based on a longitudinal case study of a high tech start-up, this paper explores how different forms of entrepreneurship coexist and interplay to create a firm's innovative dynamics. A particular focus is given to knowledge-based entrepreneurship linked to technological innovation and exploitation, service entrepreneurship, and organizational-marketing entrepreneurship. Findings suggest that firms can realize performance benefits when their members divide those entrepreneurial activities between themselves during the launching phase of the firm, and then adapt the configuration of the activities, and their behaviours into a managerial form during the expansion phase of the firm. Our work offers a dynamic view of the conditions a firm has to fulfil to survive in a knowledge-based environment and we analyse the process that produces a good integration of plural-entrepreneurship behaviours.
\end{abstract}

\footnotetext{
* This paper has been produced in the context of the research project "Knowledge-Based Entrepreneurship: Innovation, Networks and Systems” (KEINS). Financial support by the European Union, FP 6 Project 5060022, is gratefully acknowledged.
} 



\section{Plural-entrepreneurial activity for a single start-up: a case study}

Since many decades the emergence and development of firms have questioned researchers in different fields and a general consensus as emerged that these phenomena are directly linked to the entrepreneurial activity. However this observation merely shifts attention from the study of an institution genesis to the study of the entrepreneurial activity but does not directly help to clear the picture. Furthermore, the recent development of knowledge-based entrepreneurship adds new questions to the general debate (Garavaglia and Grieco, 2005).

Difficulties during the start-up creation phase and later during the development process are plural. To the classical difficulties that entrepreneurs encounter in each new firm endeavour the knowledge based entrepreneur inherits difficulties coming from his domain of activity. Namely he sets-up a firm for exploiting an innovative high-tech product, for which the market is in its infancy or does not exist. Several studies conclude that many high potential start-ups fail during the first years despite the interest of their innovative product, the adequate business model and the competences of the entrepreneur and employees. In this work we try to identify the reason behind this observation. Our argument is that the difficulties come from the combination of entrepreneurial activities needed to start and exploit successfully the firm. Not only must the entrepreneur be "knowledge-based" in the sense of innovating in a high technology environment but he must also be entrepreneurial in the organization of the new activity, entrepreneurial in the marketing mix and business model elaboration and so on. This need for simultaneous plural-entrepreneurial efforts in the early days of the firm is a major source of firm decay.

In a first section we review some definitions of knowledge-based entrepreneurship and sort out the most relevant ones for the present case study. The definition of entrepreneurship and of the hypotheses to be explored during the case study part is important because it influences the research design and the selection of the firm. The knowledge-based stream of entrepreneurial research focuses largely on high-tech start-ups, this work follows this broad research flow.

The next section is a discussion of the case study methodology employed and a presentation of the originality of the firm studied. On the basis of the definitions retained we use a dynamic perspective, in order to capture the different modifications of the social, cultural, economic and managerial networks and purposes of the firm founders (the knowledge-based 
entrepreneurs). This broad approach perfectly reflects the diversity of the problems that the entrepreneur encounters during the creation and development of the firm. The following section sums up and analyzes the interview and archival data, in particular the process pattern of time-oriented events and the implication of these events (as they are felt by the entrepreneurs). A final section highlights the findings as well as the implications.

\section{Knowledge-based entrepreneurship, theory and early case studies}

Research on high-tech start-ups is a growing field of inquiry in the economic and managerial literature. The major recession for many start-ups at the beginning of this century confirmed the need to understand their difficulties for surviving and the specificities of the knowledgebased entrepreneur behind those firms in comparison to regular entrepreneurs. The academic literature defines a high-tech start-up as a young firm (less than 8 years) launched by individuals for developing and exploiting (in various forms) an innovation, (Shaw, 1990; Freeman, 1982). Regular entrepreneurship defines that innovation can be a product, a service, a process, a new commercial or organizational scheme. Knowledge-based entrepreneurship develops a somewhat different definition, which implies that the firm is a plural innovative bundle.

\subsection{Knowledge-based entrepreneurship definition}

Can there be entrepreneurship without knowledge? Obviously the answer is no. An entrepreneur must have previously acquired knowledge to understand the industry she aims at. Therefore a criterion of previously existing knowledge is not useful because it does not make it possible to distinguish regular entrepreneurship from the specific form we wish to study. Garavaglia and Grieco (2005) propose a classification.

Based on their work we propose that can be labelled knowledge-based entrepreneurship those entrepreneurs who meet at least two of the following conditions: (i) creation of a new combination, (ii) creation of new knowledge, (iii) employ knowledge developed originally in science.

Let us take a closer look at those combinations. The combination of (i) and (ii) is an extension of the Schumpeterian entrepreneur. Following Schumpeter's definition strictly, his entrepreneur is not always a knowledge-based entrepreneur because the entrepreneurial activity is the creation of new combinations of existing knowledge. This produces new 
information, but not new knowledge. If we couple the Schumpeterian definition with the creation of new knowledge (not simply intuition, awareness, information..) we obtain a knowledge-based entrepreneur. We can notice that, following our definition, a newtechnology based firm is a knowledge-based enterprise, but all knowledge-based enterprises are not new-technology based, therefore we differ here from some definitions (Ben-Ari and Vonortas, 2005:5). The combination of (i) and (iii) corresponds to the commercial exploitation of science-based knowledge. The entrepreneurs combine this new knowledge with existing products/services and integrate them with organizational practice. By definition the new to the market science-based knowledge needs a special treatment to be commercially exploitable, therefore it is an entrepreneurial activity. The combination of (ii) and (iii) corresponds to the development of new knowledge built on science. The commercial exploitation of such a combination imposes the creation of a new organizational form, therefore it implies an almost automatic inclusion of condition (i).

The message that we try to deliver here is that the exploitation of new knowledge, sciencebased or not, implies the need to be entrepreneurial, not only for creating and exploring the knowledge, but also in bundling all the activities around the exploitation of the new knowledge.

Arguments extending this view are given by Witt and Zellner (2005). For those authors a broad range of knowledge is needed to successfully accommodate the innovative patented technology and to commercially exploit it. Making the patented technology suitable for the market sphere, developing specific commercial and organizational practices is a core element of knowledge-based entrepreneurship. Witt and Zellner label those plural-entrepreneurial activities "entrepreneurial services" in opposition to the managerial services corresponding to the execution and supervision of existing ideas and operations initially described by Penrose (1959:32). Radosevic (2005:29) distinguishes the plural-entrepreneurial activities in three main domains, the recognition and exploitation of technological (science-based) opportunities, of market opportunities and of institutional opportunities.

To achieve commercial success the new technologies must be placed into a representation of future markets (Boisot and MacMillan, 2004). After this common representation building between the different entrepreneurs the resource gathering operations and coordination can go on. Subsequently a third entrepreneurial dimension appears, corresponding to the integration of the technological knowledge into the organization and commercial functions. This integration is not trivial and, with respect to the novelty in the product or service offered by 
the firm, a new organizational form must be put forward. Becker et al. (2004) propose an interesting distinction between the division of labour and the division of knowledge. The authors note that the division of labour and specialization are amongst the most important driving forces of the performance of organizations, and thus, the most important determinants of their strategies because this division influences the competences and routines developed inside the firm. Although this division influences the future development of the firm, it also needs a specific knowledge to be done. We argue that there is no need for the knowledge division to be performed by a sole entrepreneur following Schumpeter's own idea as recalled by Cohendet et al. (2000): "the entrepreneurial function need not be embodied in a physical person and in particular in a single person. Every social environment has its own ways of filling the entrepreneurial function ... Again the entrepreneurial function may be and often is filled cooperatively. With the development of the largest scale corporations this has evidently become of major importance: aptitudes that no single individual combines can thus be built into a corporate personality; on the other hand, the constituent physical personalities must inevitably to some extent, and very often to a serious extent, interfere with each other. In many cases, therefore, it is difficult or even impossible to name an individual that acts as 'the entrepreneur' in a concern", (Schumpeter 1949: 71-2). The genitor of the business conception transforming the technological device into a commercial activity is ideally placed for selecting the good resources (employees) and determining the organization. Since many firms have several entrepreneurs at their origin, each of them has authority for performing this task or a part of it. Without entering in an Alchian-Demsetz team production debate or its knowledge-based equivalent, we can assume that the entrepreneurs know each other well and that the division of tasks between them is done naturally. After that each of them organizes the division of knowledge in his field of experience, his domain of competence in the firm (R\&D, production, branding ...). This assumption of a natural division of the tasks allows us to avoid a difficult governance debate. This difficult question of how to interpret and to coordinate the actions of several entrepreneurs if the division of tasks and responsibilities between them is not natural, if there is an entrepreneur who claims leadership over the others, is tackled partially by Mintzberg and Waters (1982) and Zander (2007).

As long as the entrepreneurs participate in the development of the new organization (or new technology following their field of expertise) they are legitimate to, and do, knowledge division. When the product becomes less innovative, and the knowledge of the employees becomes closer to that of the founders then the entrepreneurs turn into managers. 
Some authors have already attempted to explore the phase between the entrepreneurial and the managerial activity. Among others Burger-Helmchen (2007) proposes a simulation model where the distinction is made between the entrepreneur responsible for the exploration of new technologies and the manager in charge of the exploitation. The critical part between these two periods corresponds to entrepreneurial management. The model concludes easily that the most successful firms are those who adapt their entrepreneurial and managerial resources between the exploration and exploitation phases following a life-cycle approach. Regardless of the evaluation technique used by the authors to know how to alternate between the exploration-exploitation phases, those works give no indication of how this is done concretely in a firm. Therefore we look at some case studies.

\subsection{Knowledge-based entrepreneurship in some case studies}

Some case studies already explored the concept of knowledge-based entrepreneurship. They represent the entrepreneurial activity as a whole, where a distinction is often made on the basis of a sole individual characteristic, a sole discipline or unit of analysis. This can be explained by several factors, the voluntary desire to use a specific approach, or the difficulty to carry on simultaneously the work on all dimensions. Of course we do not pretend to be able to perform such a poly-dimensional analysis in our own case study, but we insist on the links between the different elements and the plural-entrepreneurial dimension.

Knowledge oriented entrepreneurship has been studied at different levels of analysis and in different contexts e.g. in new transition environment (Bishop, 2006; Woodward, 2006), in the laser industry (Buenstorf, 2006) in biotech firm (Bureth et al., 2006; Brink and McKelvey, 2006), phone services (Brusoni and Corrocher, 2006).

All those works put forward that to be successful an entrepreneurial firm must have many links to existing firms or institutions and must be able to tie them together:

- links with science (public or private) in the case of biotechnology firms and the laser strings,

- links with institutions, in the case of biotech for the agreement reason, for obtaining contracts and a sufficient level of demand for the products in the early time of the firm (which is often lacking in transition countries)

- links with other firms in the industry, in the case of the development of standards 
- Links with customers to develop the adequate business model...

The scientific network exerts of course of a great importance to obtain the necessary knowledge. But as noted by Johansson (2005) this network gives the necessary technological knowledge but does not (and should not) offer a commercial view of how to exploit it. This is obtained by developing a relation with customers, and the network of other product suppliers that provides access to the customers. The network necessary to be a successful knowledgebased entrepreneur sheds also new light on Porter's five force scheme (more recently Jocobides and Winter, 2007, used the Porterian value chain to characterise the specific value added by the entrepreneur). What are the forces of the providers and distributors working with the entrepreneur in a knowledge-based approach?

Based on the previous consideration we propose the following configuration of the pluralentrepreneurial dimension able to bring success (or not) in the start-up phase of a high-tech firm.

Figure 1. Plural-entrepreneurship and outcomes at the firm level

Dimension of entrepreneurship Outcome good (bad)

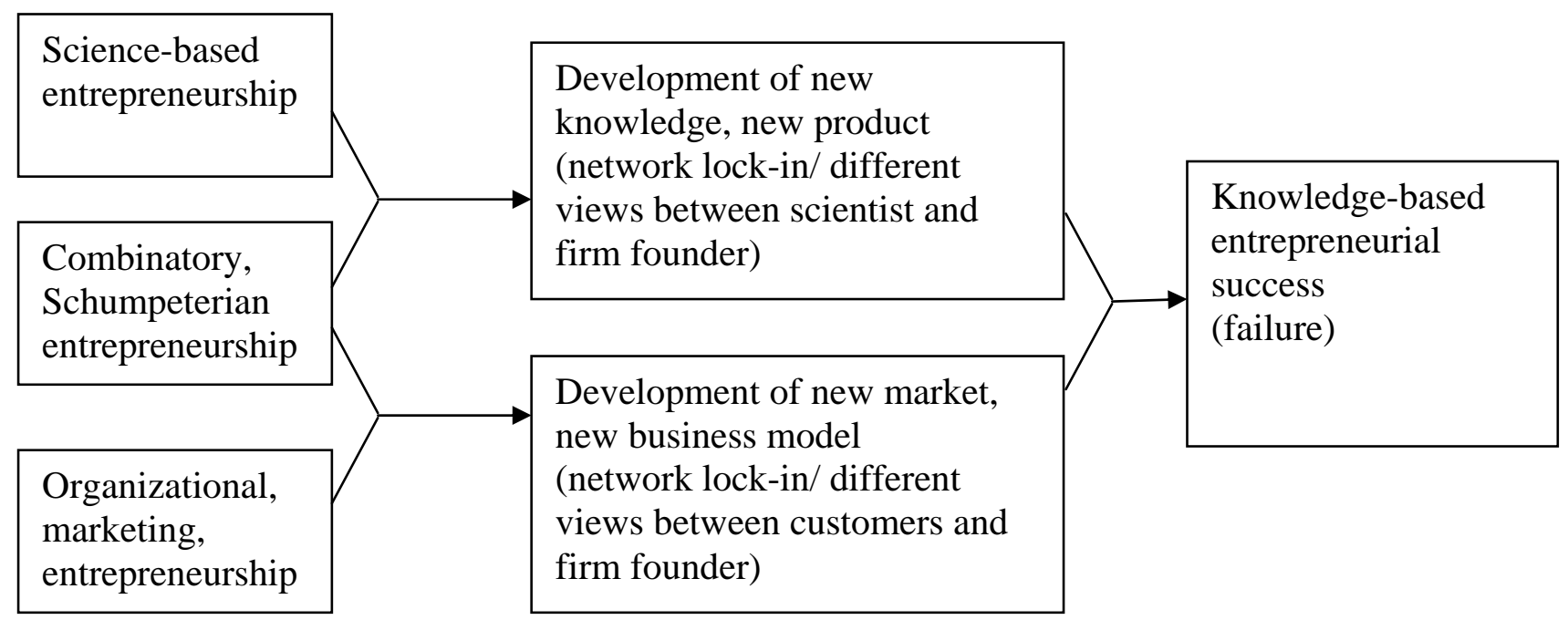

In this representation the success of a firm corresponds to the outcomes of pluralentrepreneurial activities. Those activities must join into a coherent business strategy during the start-up phase. Therefore this view is aligned with the concept of entrepreneurial strategy by Mintzberg et al. (1998). They define entrepreneurial strategy as: 
“(...) characterized by a visionary process: strategy exists first of all in the leader's mind as a long-term direction, a vision of the future and of the results of the organization. Such a strategic vision tends to be malleable, and due to this, entrepreneurial strategy often appears to be both deliberate and emergent, deliberate from the point of view of its global vision, and emergent in the way in which the details of the vision evolve."

This definition of an entrepreneurial vision, linked with an evolutionary theory of the firm is also very present in the works of Witt $(1998,2007)$.

The necessity to be entrepreneurial along several dimensions requires a procedural approach to describe the evolution of the entrepreneurial activities (Bernasconi and Moreau, 2005). Previous work on that topic developed our knowledge of the common traits on the genesis and growth of the firms, for instance they gave us a good understanding of the different phases of the development of firms (following a life cycle model) but by definition this separation in phases (or steps) focuses on the important points in each phase, neglecting somehow the relationships between the different elements and their co-evolution. The picture is then composed of the entrepreneur(s), the innovative products or services, the supporting activities, and the financial resources. The co-evolution of all these elements in relation with entrepreneurship fosters the survival of the firm.

In the following we present the research methodology and the characteristics of the firm we selected for our case study.

\section{Research methodology, firm selection and presentation}

Because our main concern is to understand the evolution path of a high-tech firm from an knowledge-based entrepreneurship perspective, we collect and analyze the data following a longitudinal case study methodology. Such an approach leaves plenty of room for interpretation, validation or reformulation of hypotheses by repeated interviews and confrontation of the answers given by the respondents. This allows us to sketch somehow the motivations and rationality of the entrepreneurs interviewed.

The plural-entrepreneurial context we try to observe depends on the interaction of three types of elements, each of them can (and does) independently evolve during the life-cycle of the firm. The first type corresponds to the individual traits of the entrepreneur (the motivations that made him start the firm, what pushes him to be an entrepreneur...). The second type corresponds to the innovative elements and because we speak about plural entrepreneurship 
those elements take the form of a triplet technology - product and service - market. Finally the third correspond to the organization elements on the firm and the industry levels.

These qualitative data obtained by interviews are completed by standard quantitative information (financial and accounting data) and also quantitative data issued by the entrepreneurs themselves such as the expected growth rate of the firm and the industry or of the employee turnover.

\section{Data collection and data analysis}

To appreciate the evolution of the firm we obtained documents, aimed to investors, at different phases of the firm, where the aims, products and market of the firm are presented. To understand these documents and sometimes the real motivation behind them that do no always show through these factual data we conducted several semi-directive interviews with the entrepreneur and the management team.

We had also access to an amount of information coming, among others, from reports, press releases, advertising articles... Because these data can have different origins (internal or external to the firm), we verified their mutual coherence. In the following we describe the firm under the name $\mathrm{F}$

\section{The firm selection}

The firm studied, to be considered as a knowledge-based entrepreneurial attempt, had to be a high tech start-up. To select such a firm we used a firm set built in the context of the research project 'Keins' on knowledge-based entrepreneurship. To be relevant we had to ensure that the firm founder was a knowledge-based entrepreneur, we did that by selecting a firm where the founder was also the owner of the patent at the origin of the firm.

We sought a firm founded by people whose main reason for starting the venture was the willingness to develop their own business conception independently of the business conception of their previous employer. We also looked for a firm having relations with different networks and who gave importance to the knowledge they had obtained from their previous work on the customer needs, the technology, the suppliers, competitors and institutions (by looking at the financial help they obtained). Finally, to be relevant on the plural-entrepreneurial schema, the founders of the firm must consider of critical importance their specific technological knowledge and marketing/organizational entrepreneurial activity. The founder of firm F, met all these criteria. 
Firm F was created in August 2000, by entrepreneur A and B. Both are owners of the patents at the origin of the firm. Entrepreneur A is now CEO of the firm and supervises the international development of the firm. Previously he was employed as an international brand manager for a major phone company, among others he was in charge of the system convergence between different phone operators. Before that he worked as IT consultant for McKinsey. He holds a master diploma in IT engineering. Entrepreneur B is now CSO of the firm. He was previously employed as a project chief for developing new products by a major telephone operator. Before that he worked in the field of technical development for another major phone builder in California. He holds an engineering diploma. Both entrepreneurs have an MBA from a major international business school.

Firm $\mathrm{F}$ is active in the field of multi-country mobile telecommunications, providing initially its services in France, Luxembourg, Belgium and the Netherlands. In 2007 the firm entered the UK market and plans for 2008 to expand its operation to Germany, Switzerland and 2 non European countries. The firm offers services addressing two different target groups. Firstly, it serves the end-user segment, providing a multi-country contract solution which allows frequent travellers to reduce roaming costs significantly. Secondly, firm F offers to other enterprises that want to create their own brand of phone services to share its spectrum of license agreements and their know-how. Thanks to her unique, patented, technology firm F allows the customer to avoid expensive roaming fees.

Roaming is a general term in wireless telecommunications that refers to the expansion of connectivity services in a geographical location different from the original home location where the service was registered. Roaming occurs when a wireless service subscriber uses the facilities of another wireless service provider than the one he subscribed to. This second provider has no direct pre-existing financial or service agreement with this subscriber to send or receive information. The typical example of "roaming" is in the use of cellular phoning when a phone is in a location where its wireless service provider does not provide coverage (for example, another country). Roaming fees are traditionally charged on a per-minute basis and they are typically determined by the service provider's pricing plan.

The business idea is based on several patents which allow them to have numerous regional numbers, e.g. a French and a Belgian one, on the same SIM phone card. The user has to choose one "active" line; logically depending on his location. The other lines are on 
"inactive" mode, they can receive calls which are forwarded to the active line. For example if the user is located in France, his French line is active, he can call at local rates (ranging from 14 to 22 cents per minute for domestic calls), receiving calls to his French number at no cost and calls to his Belgian number for a forwarding cost of 18 cents per minute. Compared to an average roaming price of 85 cents per minute, possible cost reductions for firm F's customers are obvious. Furthermore the consultation of the voicemail from the subscribed country is free. In addition, thanks to a unified message service, customers can access and manage their messages (voicemail, fax and emails) not only from their mobile phone but also from the internet or any other phone. Roaming outside the subscribed countries is charged at the average industry price.

Firm F is a Mobil Virtual Network Operator (MVNO). An MVNO is defined as a company providing mobile subscription services under its own brand name without having a spectrum licence (the firm does not have her own mobile phone network). They target a market niche which is not well served by the incumbents by settling an agreement with major national phone operators, buying a package of phone minutes and reselling them to individuals and firms adding specific services.

Firm $\mathrm{F}$ has agreements with major national phone operators in different countries where the firm provides her services. Firm F does not only target the retail business, its agreements include the right to resell their interconnection right to other MNVOs, which makes the company a Mobil Virtual Network Enabler (MVNE). An MVNE provides infrastructure and services to enable MVNOs to offer services to end-user customers.

In January 2002 the company has also launched a mobile service under its own brand targeting international frequent travellers and bringing 30\% to $100 \%$ price reduction on GSM mobile roaming charges plus improved seamless services.

\section{Results}

\subsection{General results}

As mentioned earlier, the purpose of this research is to understand the evolution of the different entrepreneurial mindsets and activities, looking especially at the differences between the initial and the current situation. Table 1 presents the results of the research, the description, and the main factual differences exhibited by the entrepreneurs; the architecture of this table follows partially Bernasconi and Moreau (2005). 
The development of firm F, is a relatively smooth one when we look at the minor differences existing between the initial business plan and the real implementation.

The distinct feature of firm $\mathrm{F}$ is that she constantly acted in such a way as to exploit her patented technological base. Unfortunately, but not surprisingly for the founders, the quest for profitability took several years. Launched in 2000, firm F reached profitability for the first time in 2004. Meanwhile the firm had to raise 5.3M€ at different steps of development between 2000 and 2006 and had to manage the financial crisis of the IT sector between 2001 and 2003. Since her start in 2000, firm F almost has doubled her turnover each year, reaching 6.2 million euros in 2005. Employment has grown fast since the launching of the MNVE activity, amounting today to more than 60 persons, which represents three times the enrolment at the beginning of 2005 .

Table 1. Difference between realisation and forecast

\begin{tabular}{|c|c|c|}
\hline Characteristics & Factors observed & $\begin{array}{l}\text { Scale of difference between } \\
\text { forecast and realisation }\end{array}$ \\
\hline $\begin{array}{l}\text { Precision of strategic } \\
\text { positioning }\end{array}$ & $\begin{array}{l}\text { Segmentation : choice between presence in a } \\
\text { micro-segmentation, in several associated } \\
\text { micro-segments or not, mass market (industry } \\
\text { and or private); } \\
\text { Value chain : choice of specialisation in one or } \\
\text { several functions of the chain, or in the totality; } \\
\text { the offer: choice of offer in terms of product, } \\
\text { services, and geographic reach; } \\
\text { Type of innovation: choice of innovation, } \\
\text { incremental, major or radical }\end{array}$ & $\begin{array}{l}\text { Minor differences } \\
\text { Segmentation adequate, offer, } \\
\text { value chain and competitive } \\
\text { advantage. Some minor differences } \\
\text { in the marketing strategy and in the } \\
\text { balance between the two activities } \\
\text { of the firm. }\end{array}$ \\
\hline Level of ambition & $\begin{array}{l}\text { Explanation of the vision: explicit or implicit } \\
\text { indication of hoped-for future; } \\
\text { Evolution of the capital: stock market launch, } \\
\text { trade sale, independence; } \\
\text { Hoped for leadership: local regional, national, } \\
\text { international; } \\
\text { Speed of achievement of fixed objectives: from } \\
\text { one to x years }\end{array}$ & $\begin{array}{l}\text { Minor differences, } \\
\text { due to a good technological } \\
\text { knowledge and adequate financing } \\
\text { major objectives are reached. Some } \\
\text { countries initial aimed at have not } \\
\text { yet been covered by the service of } \\
\text { the firm, but on the other hands } \\
\text { other countries are more open than } \\
\text { expected (Africa) }\end{array}$ \\
\hline $\begin{array}{l}\text { Anticipation of } \\
\text { implementation }\end{array}$ & $\begin{array}{l}\text { Managerial resources and skills: functional } \\
\text { skills (financing, technological, marketing, } \\
\text { strategic and organisational), transversal } \\
\text { (negotiation, managing relationship, } \\
\text { contracting, project management, } \\
\text { internationalisation); } \\
\text { Organisational resources and skills: structuring, } \\
\text { role of network, responsibilities and decision- } \\
\text { taking, information systems, etc; } \\
\text { technological resources and skills: acquisition, } \\
\text { development, construction, protection }\end{array}$ & $\begin{array}{l}\text { Minor differences, the } \\
\text { development option has been } \\
\text { followed, but larger importance of } \\
\text { marketing than initially thought }\end{array}$ \\
\hline $\begin{array}{l}\text { Accuracy in } \\
\text { quantitative indicator }\end{array}$ & $\begin{array}{l}\text { Staff; } \\
\text { Turnover }\end{array}$ & $\begin{array}{l}\text { significant differences, } \\
\text { Staffing, same, then higher than } \\
\text { anticipated } \\
\text { Turnover: almost as anticipated }\end{array}$ \\
\hline
\end{tabular}


We can draw a number of observations from the analysis of the knowledge-based entrepreneurial behaviour. The founding team, for the reason because of their previous experience in close industries and commercial training, made a realistic and suitable analysis of the market and conceived an appropriate technology. It is also worth noticing that market entry was eased by some major national players with whom the entrepreneurs had contacts before the launching of the firm. Therefore we will take a closer look at the social network of the entrepreneurs in the following.

As in every case study, carried out after the start of the firm, it is difficult to reconstruct the original ambition and to draw the mindset of the entrepreneur at that time on the basis of documents and interviews. Also, we cannot tell whether the evolution of the firm and of its capital corresponded to the real intended plan. However the initial plan seems to us to be coherent and the final outcomes are close to the initial mindset we deduced. The major source of variation is related to the time horizon. This variation can be in disfavour of the firm (time to be profitable) but also favourable (time to develop other activities around the initial project).

\subsection{Plural entrepreneurial activity oriented results}

We identified three types of entrepreneurial activity that enabled the firm to overcome the problems a start-up faces in her early days: science-based entrepreneurship (patenting activity), marketing entrepreneurship (to communicate around a new type of product), and combinatory entrepreneurship (to tie together a new technology and a new type of business model). The plural-entrepreneurial activity embodied by the founders together with their relationship, allowed the firm to develop their external relationships to obtain new information, new contracts, and new sources of financing.

\section{Combinatory entrepreneurial activity}

When starting their firm, the entrepreneurs had to choose between a wide range of possible business models, each entailing advantages but also technical, legal and managerial challenges. They chose to focus on one type of activities at the beginning of the start-up activity, and deliberately ignored some other forms of activities they could perform with the patented technology. 
The combinatory entrepreneurial task was performed by several people, with different levels of implication in the firm: the two founders, and the main financer. This was the only entrepreneurial activity done by several people. First, this focalization allowed the firm to avoid being overloaded with tasks and problems. The overload occurs when too many tasks must be coordinated by a small number of individuals. Secondly, they focused on a business model that was new, but close enough to their previous activities in major phone companies. Therefore they could use their former relation network and build on it to obtain new focused relations. At the same time, the entrepreneurs could feel assured by one of the major financers who approved their business model strongly so that the two founders could focus on their main entrepreneurial activities: science-based entrepreneurship for one, and marketing entrepreneurship for the other. The combinatory entrepreneurship existed because there where other forms of entrepreneurship that needed to be coupled with resources and competences in a new manner.

\section{Science-based entrepreneurship}

One of the founders of the firm took on the science-based entrepreneurial activity. At the launching of the start-up, the technical problems were for the most part already solved. The most urgent critical task was to obtain the patent (which is not entrepreneurial). Science-based entrepreneurship needed to be realized in the integration of the firm's technology with other exiting technologies, in such a way as to obtain a sellable service.

\section{Marketing entrepreneurship}

Because the product was new, the way to communicate about it needed a new form of entrepreneurship.

\section{The importance of the plural-entrepreneurial organization of the firm}

This part of the study explored the configuration, evolution and organization of the pluralentrepreneurial firm. This approach enhances research on entrepreneurial networks and dispersed form of entrepreneurial activities (Minkes and Foxall, 2003). Such an approach certainly extends our understanding of organizational inertia and adaptability capacities and helps to explain the dynamics of knowledge-based start-up founding. Let us say some words about the effects of the plural-entrepreneurial configuration on the performance of the firm. 
We identified three forms of entrepreneurial activity, but not all had received the same amount of resources and time from the founders. Resource allocation between the pluralentrepreneurial activities is certainly a source of performance (and survival) of the firm. Contrary to our intuition, the science-based entrepreneurial activity and marketing entrepreneurship were not the most important in the early stage of the firm. The firm already had a technology (but to be patented) at the beginning. The most crucial task was to coordinate all the elements of novelty to obtain coherence in the activities and cohesion between the employees. The need for coherence and cohesion was also pregnant in the relation with the partners (a limited number in the beginning). Our findings suggest that this research is an entrepreneurial activity because it contains a large part of novelty, and that this part fosters the successful emergence and initial development of the start-up.

This configuration of plural-entrepreneurial activity proved advantageous for the performance of the firm because it gave the capacity to be connected with a diverse set of external partner in a broad range of important firms and to integrate all the information internally.

Discussions with the founders in summer 2007 also showed that, during the period where only one of the entrepreneurial activities was followed, the firm did not do well. The firm had to manage to align the three entrepreneurial activities, but each activity needed to be focused on one task. It thus seems important for both theory and practice to be concerned about the factors that constrain and enable a firm to identify and adapt the entrepreneurial activities with changing knowledge, environment and resources.

This also suggests that it can be fruitful for researchers to consider the interplay between different forms of entrepreneurship. Plural-entrepreneurship is generated and maintained by individuals. As our study tries to show strong and cohesive ties at the individual level have a positive effect on the firm performance and we believe that the more heterogeneous the entrepreneurial tasks, the more important the cohesion between the individuals.

A theoretical contribution of this plural-entrepreneurial study to the literature consists in showing that the way the firm manages the entrepreneurs is important to understand the dynamic links between the individual in the firm and outside of the firm. Specifically, our findings suggest that when a firm delegates the responsibilities to specialized entrepreneurs then attempts to extend the range of activities can be dangerous and harm the firm profitability. 


\section{Conclusions and implications}

Some issues emerge from the analysis of firm F. There is a clear need for adapting the commercial behaviour of the firm to the technological innovation. The emphasis on the marketing and organization setting as an entrepreneurial activity was necessarily done contemporary to the technological entrepreneurial task.

One of the major problems at the beginning of the firm was the anticipation of the adoption pace of the services provided by the customers. In contrast, the organization which needed to be implemented was relatively well anticipated. This relatively smooth development comes probably from the fact that the major patent and the major technological development were obtained shortly after the foundation of the firm.

The objective was to deepen our understanding of knowledge-based entrepreneurship on the basis that such a kind of entrepreneurship must almost simultaneously be flanked with other forms of entrepreneurial activity. The high-tech start-up we analysed showed that in reality this is true and that the evolution of firm F was mainly a plural-entrepreneurial attempt in the first years, and that it turned out to be more managerial along the several dimensions observed at the same time. This represents a significant evolution, therefore we observe a strong modification of the firm between its infancy and today's development phase (still too early to speak about maturity phase). Again we emphasise the importance of the triplet technology, product and service, market and the related entrepreneurial tasks and the more standardised activity of financing.

It is clear that failing in one of the above triplet elements would have been a hard blow for the firm hindering her development and profitability. Therefore the plural-entrepreneurial activities must be conducted in a coherent way. In this case there was a lack of control from above. It did not harm the firm because the founders had a similar background and a common view of the development of the firm. This common background is the main reason of the coherence of the firm decision: in the absence of this common background the control could have been given to a general manager (responsible for task allocation in a knowledge-based firm, Cohendet and Llerena, 2006:22) or sometimes to the financer. 


\section{References}

Becker M., Cohendet P., Llerena P., 2004, "Division of labor and division of knowledge in the evolutionary theory of the firm: A babbagian perspective", Schumpeter Society, Innovation, Industrial Dynamics and Structural Transformation: Schumpeterian Legacies, Milan, Italy, 9-12 June 2004.

Ben-Ari G., Vonortas N., 2005, Risk Financing for Knowledge-Based Enterprises: Mechanisms and Policy Options”, Keins WP0bis.

Bernasconi M., Moreau F., 2005, "From forecast to realization - a systemic approach to understanding the evolution of high-tech start-ups”, in A. fayolle, P. Kyrö and J.Ulijn (eds), Entrepreneurship Research in Europe; Outcomes and perspectives, Edward Elgar Publishing, 174-192.

Bishop K., 2006, "Knowledge Based Entrepreneurship in the Czech Republic and Hungary: Results from 4 case studies”, Keins WP12.

Boisot M., MacMillan I.C., 2004, "Crossing Epistemological Boundaries: Managerial and Entrepreneurial Approaches to Knowledge Management”, Long Range Planning, 37, 6, 505524.

Brink J., McKelvey M., 2006, “The struggling biotechnology firm: Technological regimes and firm performance in sub-sectors”, Keins WP16.

Brusoni S., Corrocher N., 2006, "The development and commercial success of SMS: Standard committees as engine of knowledge-based entrepreneurship”, Keins WP13.

Buenstorf G., 2006, “Knowledge-based entrepreneurship and technology transfer: Evidence from the German laser industry”, Keins WP15.

Bureth A., Pénin J., Wolff S., 2006, "Entrepreneurship in biotechnology : The case of four start-ups in the Upper-Rhine Biovalley”, Keins WP17.

Burger-Helmchen T., 2007, "Entrepreneurs, managers and entrepreneurial management: Effects on firm profitability”, Workshop - Lucca 19-20 January 2007, Internal organisation, cooperative relationships among firms and competitiveness.

Cohendet P., Llerena P., 2006, "Knowledge-based entrepreneur: The need for a relevant theory of the firm", Keins WP6.

Cohendet P., Llerena P., Marengo L., 2000, "Is there a pilot in the evolutionary theory of the Firm?”, in N. Foss, V. Mahnke (Eds.), Competence, Governance and Entrepreneurship, 95-115, Oxford University Press, New York.

Freeman C., 1982, The Economics of Industrial Innovation, Frances Pinter.

Garavaglia C., Grieco D., 2005, "Hand in hand with entrepreneurship, a critical overview from entrepreneurship to knowledge-based entrepreneurship”, Keins WP 0. 
Jacobides, M.G, Winter S.G, 2007, "Entrepreneurship and firm boundaries: The theory of A firm”, Journal of Management Studies, 44, 7, 1213-1241.

Johansson M., 2005, “Networking the knowledge-based entrepreneurial firm”, Keins WP7a.

Maurer I., Ebers M., 2006, "Dynamics of social capital and their performance implications: Lessons from Biotechnology start-ups”, Administrative Science Quarterly, 51, 262-292.

Minkes A.L., Foxall G.R., 2003, "Herbert Simon and the concept of dispersed entrepreneurship”, Journal of Economic Psychology, 24, 221-228.

Mintzberg H., Ahlstrand B., Lampel J., 1998, Strategic Safari, The Free Press.

Mintzberg H., Waters J.A., 1982, “Tracking strategy in an entrepreneurial firm”, Academy of Management Journal, 25, 3, 465-499.

Penrose E., 1959, The theory of the growth of the firm, Oxford University Press.

Radosevic S., 2005, "National systems of innovation and entrepreneurship: In search for a missing link”, Keins WP4a.

Schumpeter, J.A., 1949, Economic Theory and Entrepreneurial History - Change and the Entrepreneur; Postulates and Patterns for Entrepreneurial History. Cambridge, MA: Harvard University Press.

Shan W., 1990, “An empirical analysis of organizational strategies by entrepreneurial hightechnology firms”, Strategic Management Journal, 11, 2, 129-139.

Witt U., 1998, "Imagination and leadership: The neglected dimension of an evolutionary theory of the firm”, Journal of Economic Behavior \& Organization, 161-177.

Witt U., 2007, "Firms as realization of entrepreneurial visions", Journal of Management Studies, 44, 7, 1125-1140.

Witt U., Zellner C., 2005, "Knowledge-based entrepreneurship: The organizational side of technology commercialization”, Keins WP 8.

Woodward R., 2006, "Knowledge-based entrepreneurship in two transition countries”, Keins WP14.

Zander I., 2007, "Do you see what I mean ? An Entrepreneurship perspective on the nature and boundaries of the firm”, Journal of Management Studies, 44, 7, 1141-1164. 